\title{
URBAN PROBLEMS \\ AND RURAL SOLUTIONS: \\ DRINK AND DISESTABLISHMENT IN THE FIRST WORLD WAR
}

by STUART MEWS

(

VER ten years ago Brian Harrison drew attention to certain inadequately explored areas 'where Marx's classes still make their appearance but are overlain by the more lasting dichotomies of traditionalist versus radical, provincial versus Londoner, town-dweller versus countryman, intellectual versus the mass, Anglican versus Nonconformist, male versus female'. ${ }^{1}$ This paper does not isolate the urban-rural dichotomy which for most of the twentieth century has chiefly acquired a separate social significance only in and through the romantic speculations of intellectuals, ${ }^{2}$ but assumes its importance as one of several factors in interaction with each other which have divided and sometimes united societies and segments of societies along horizontal rather than vertical lines. Two areas which demand that complex analysis, sensitive to social and cultural crosspressures, proposed by Harrison, are leisure (an area in which he has himself practised with distinction what he has preached) and secularisation. This paper considers one aspect of each of these, namely drink and disestablishment, as they impinged upon each other in a very specific episode in I9r5.

Drink and disestablishment are two topics which raised issues and were the subject of agitations generally recognised as important for an understanding of nineteenth century Britain but usually regarded as at most of only marginal significance in the twentieth. ${ }^{3}$ Yet though

1 Brian Harrison, 'Religion and Recreation in Nineteenth Century England', PP 38 (December 1967) p 98.

2 I would not go quite so far as a former colleague in arguing that the rural peasant 'became socially acceptable only through the romantic speculations of nineteenth century German intellectuals', Bryan S. Turner, Weber and Islam (London 1974) p 95. but for a discussion of some of the difficultics in the use of this and other similar dichotomies sec Stuart Mews, 'Community as a Sociological Concept', The Christian Community, ed Laurence Bright (London 197I) pp I-40.

3 D. A. Hamer, The Politics of Electoral Pressure. A Study in the History of Victorian Reform Agitations (Hassocks 1977); Pressure from Without in Early Victorian England, ed P. Hollis (London I974). 
the power of their electoral appeal was steadily diminishing in society as a whole, the drink and disestablishment questions retained a special prominence in the often out-moded social and political ideologies of religious institutions, institutions which like the British army were frequently found to be fighting the wars of the present with the weapons of the past. It was true that profound changes of attitude were taking place in the minds of younger Christian leaders but when Harold Anson lived in Manchester between 1910 and 1919 he found that 'Church circles were scarcely interested in any other cause except the disestablishment of the Church in Wales, and the maintaining of Anglican rate-supported schools', to which he later added as a third cause for concern: opposition to licensing restrictions. Churchmen did dislike drunkenness, Anson noted, 'but they believed in the public house':

Generally speaking they distrusted the man who did not like his glass of ale. The pious Lancashire churchman regarded his glass of ale and a reasonable liking for the public house, as a safeguard against the fanaticism and dishonesty of which he accused his Nonconformist neighbours. ${ }^{4}$

Manchester, as Ward and Clarke have demonstrated, ${ }^{\mathbf{5}}$ was a rather special place, but its enthusiasms were not unique and could erupt in the most unlikely places at the most unexpected times. One of the most remarkable of such effusions, and one of the least understood, was the re-emergence at roughly the same time, of the drink and disestablishment questions shortly after the beginning of the first world war.

'For reasons that are still obscure', Morgan has observed, ${ }^{6}$ the chancellor of the exchequer David Lloyd George in the spring of I9IS announced his determination to settle the drink question by the nationalisation of all public houses. Lloyd George's intentions were as baffling to his contemporaries as they remain to modern historians. Why should the most prominent member of the government after the prime minister of a nation fighting the most ferocious war in its history devote months of his energies to the apparently lost cause of temperance reform? Asquith at the time thought the scheme an indication of his colleague's lack of 'perspective and judgment'; to

- Harold Anson, Looking Forward (London 1938) pp 129, 181 .

8 W. R. Ward, Religion and Society in England 1790-1850 (London 1972); Peter F. Clarke, Lancashire and the New Liberalism (Cambridge 1971).

- Kenneth O. Morgan, Lloyd George (London 1974) p 84. 


\section{Drink and disestablishment in the first world war}

Max Aitken (later Lord Beaverbrook) it was 'a strange vagary . . . somewhat rash and quixotic'. 'When a cabinet minister says drink is a greater danger than the armies of Germany', wrote a unionist opponent, 'one almost wonders whether he was sober or merely hysterical."7 Insobriety was not however, the personal weakness most readily associated with Lloyd George and though his solution to the drink question may, as Asquith insisted, have oscillated between 'two poles of absurdity' ${ }^{8}$ his resolve to push forward this particular issue was not as eccentric as some of his contemporaries seemed to think. It was in fact a political manoeuvre designed primarily as a response to something rather more than a little local difficulty which threatened his position amongst his ever fickle supporters, the nonconformists of Wales. It was an attempt to maintain the support of an increasingly rural religious sub-culture by adopting its participants' solution to what appeared to be a serious urban problem.

When war was declared in 1914 it created a sense of national unity which was hailed with relief by those social pessimists who had viewed with alarm the turbulence of the immediate pre-war period. ${ }^{9}$ But the social and spiritual solidarity of August I9I4 was superficial. Within months every pressure group and school of thought was re-deploying its arguments and putting its own programme forward as an essential ingredient for victory or as the only appropriate response to the challenge of the wartime situation. On the whole the new circumstances favoured the reactionaries rather than the radicals. Although Lord Halifax, the Anglo-Catholic leader, accused teetotallers 'for whom he had a strong aversion' of exploiting the war 'in the interests of their pernicious fad', 10 it cannot be said that they made the best of their opportunity. The production of new and topical arguments to justify old conclusions did not impress when they rested on contradictory interpretations of wartime events. Why had the German troops advanced with such efficiency and manifested such amazing resilience? Because, suggested bishop Welldon, they had not been allowed to incapacitate themselves through strong drink. Why had the Germans committed such atrocities in Belgium? Because, said

7 H. H. Asquith-Venetia Stanley 3r March 19rs quoted in [Cameron] Hazlehurst [Politicians At War] (London 1971) P $21 \mathrm{I}$; [Lord] Beaverbrook, [Politicians and the War] (London 1928) pp 71, 74; Hatfield [Quickswood] MS Qui 19/34 Arthur Elliot-Lord Hugh Cecil 8 April igrs.

- H. H. Asquith-Venetia Stanley 3 I March Igrs quoted Hazlehurst p 2 I I.

- Manchester Diocesan Magazine September 1914.

${ }^{10}$ [J. G.] Lockhart, [Viscount Halifax 1885-1934, 2] (London 1936) p 237. 
bishop Hicks, they had 'unlimited opportunities for getting themselves drunk.'11

Edward Lee Hicks, bishop of Lincoln, was president of the Church of England Temperance Society. When he raised the question of drink at the first bishops' meeting after the outbreak of war 'a general silence followed'. Only two bishops supported him and he felt keenly his isolation: 'I feel always out of my element here at Lambeth: an "outsider" . . I fear I am thought a bore or a bear, or a bounder'.12 Certainly the archbishop of Canterbury Randall Davidson, was very wary of seeming to break the wartime truce on controversial matters by pushing for a radical measure of temperance legislation, though he was prepared to warn against the treating of soldiers which had produced some unsavoury incidents and to urge voluntary acts of abstinence for the duration of the war. ${ }^{13}$ In October I9I4 he had initially declined a request from the bishop of Croydon, an old teetotal stalwart, to preside over a gathering of the temperance clans, planned on inter-denominational lines. When Croydon had taken this rebuff as a personal insult and deplored the "general lack of earnestness and enthusiasm' in the church of England, the archbishop reconsidered but his obvious lukewarmness was more typical of Anglican attitudes than the fervour of his zealous suffragan. ${ }^{14}$ What turned the tables in favour of the temperance lobby was the gradual accession of support for some of their objectives from the least likely quarter, the right-wing die-hards.

The war provided an opportunity for those forces of reaction which had formerly been on the defensive to attempt to reimpose their control of society. ${ }^{15}$ Those who had felt threatened by the pre-war self-assertiveness of the women's movement and the labour movement found the new situation particularly favourable. Women were an easy target. Did not the war prove that the full privileges of citizenship should only be granted to those who were able to answer their country's call to fight, and possibly die, in her defence? One leading Anglo-Catholic, H. F. B. Mackay, vicar of All Saints, Margaret Street,

11 Alliance News February 1915 p 29; March 1915 p 47.

${ }_{12}$ MS Diary of E. L. Hicks 2I October I9I 4 P 291.

${ }^{13}$ [G. K. A.] Bell, [Randall T. Davidson, 2] (London 1935) p 748.

14 [Lambeth Palace Library] Davidson MS: H. H. Pereira-R. T. Davidson 20 September, 6, Io October 1914; R. T. Davidson-H. H. Pereira 6 October, I2 November I914. Part of Davidson's reluctance stemmed from a desire not to compromise the 'dual basis' of the CETS by association with bodies officially committed to prohibition.

${ }^{15}$ [Samuel] Hynes, [The Edwardian Turn of Mind] (Princeton N.]. 1968) P I3. 


\section{Drink and disestablishment in the first world war}

had gone even further and had come close to suggesting that the war itself was a divine retribution for the increasing rejection by women of their traditional role. ${ }^{16}$

The image of womanhood which the clergy most liked to invoke in the early years of the war was of a creature weak either in body or will. The bishop of London in his highly successful recruiting appeals often played upon the chivalrous instincts of his hearers by portraying the angel of the home, physically weak but spiritually sensitive who relied upon male protection to stand between her and the marauding Hun. ${ }^{17}$ The obverse of this highly idealised picture was the alternative image of the working class feckless woman, who could neither manage her money nor adequately look after her home. Canon E. A. Burroughs, later bishop of Ripon, deplored the "heedlessly liberal scale' of the separation allowances that had made many women, in his words, "wealthy and idle who have never been anything but industrious and poor':

'Eighteen shillings a week, and no husband? Why it's heaven!' And 'heaven' for such people is too often hard by the publichouse; largely because the latter is the normal receptacle of spare cash and they have few other ideas of spending. And then their home goes to ruin, and the children run wild unchecked by the disciplinary influences which even a not very edifying male parent radiates. ${ }^{18}$

'It sounds horrid to say it, but the fact is that the women dependents of our soldiers are getting more money than they can wisely handle', remarked the archbishop of Canterbury. 'Money is pouring into their homes', exclaimed the bishop of London, and reminded his audience of women church workers that many wives were getting their husbands' entire earnings for the first time. Anxious about their husbands, with money in their purses and the public houses open in the mornings, the bishop of London was not surprised that many were drinking excessively. ${ }^{19}$ But canon Burroughs would not accept even these extenuating circumstances. He claimed that when social

${ }^{10}$ Church Union Gazette (London) October 1914 P 294. Mackay had long bcen obsessed by 'that contemptuous young woman': F. B. Mackay, The Religion of the Englishman (London 1911) PP 14, 25.

17 A. F. Winnington Ingram, $A$ Call To Arms (London 1914) p 7.

${ }^{18}$ [E. A.] Burroughs, [The Valley of Decision] (London 1916) p isr. Even the normally enlightened Peter Green of Salford believed that out of every r/- received in separation allowances, $3 \mathrm{~d}$ found its way to the public house: Challenge 6 November 1914.

${ }^{10}$ Bell p 747; A. F. Winnington Ingram, A Day of God (London 1914) Pp 62, 82. 
workers asked what the husband would think if he returned to find his wife drunk, 'the wife's reply is not infrequently that "she wouldn't mind if he never came back".' ${ }^{20}$ Speakers at a Roman Catholic League of the Cross meeting in Notting Hill had no doubt that drunkenness amongst women had increased, while monsignor W. F. Brown, rector of St Anne's, Vauxhall, demanded the total exclusion of women from public houses. Licensees in London did agree to a request from the metropolitan police commissioner to bar women before II $30 \mathrm{am}$, but the monsignor's request was regarded as highly insulting not just by the predictable Mrs Pankhurst'sWSPU but also by catholic supporters of the women's movement. ${ }^{21}$ Sylvia Pankhurst insisted that newspaper moralising had simply prompted the police into greater diligence in making arrests with the consequence that the increase in convictions for female drunkenness was artificially inflated. ${ }^{22}$ This contention was supported by the investigations of the NSPCC. Their inspectors reported in January 1915 that one hundred and twenty two of their branches had found that female drunkenness had decreased since the outbreak of war; in twenty six there had been an increase, but in twelve of these the situation was returning to normal. The society concluded that the charge made against soldiers' wives was 'a great slander'. ${ }^{23}$

Nevertheless the clergy, with very few exceptions, ${ }^{24}$ were only too willing to believe the worst of working class women, and to maintain mental assumptions about female weakness of will which were to reach epic proportions of credulity in the totally bogus 'war babies' scandal of April I9I5. In the earlier agitation about drunkenness nonconformists and Roman Catholics had expressed concern chiefly about the way in which the women chose to spend their money, but Anglican indignation was aroused particularly by the amount of money paid and the ease with which it was obtained. In fact the rates paid to soldiers' dependents had not changed since the Boer war but those with no other source of income could apply for supplementation to either the Soldiers' and Sailors' Families Association or the National Relief Fund. The latter was accused of 'setting out to destroy the very

${ }^{20}$ Burroughs $p 152$.

${ }^{21}$ London Catholic Herald 3 r October, 14, 28 November 19r4. On Brown see W. F. Brown, Through Windows of Memory (London 1946).

2a B. Sylvia Pankhurst, The Home Front (London 1932) p Ior.

${ }^{23} G[$ lasgow $] H[$ erald] i I January igr 5 .

24 According to Edwyn Barclay, the clergy of south London believed the charge 'much exaggerated', Challenge 2s December I9I4. 


\section{Drink and disestablishment in the first world war}

basis of Christian marriage' because it gave the same allowances to both married dependents and those whom Violet Markham called the 'unmarried wives' of soldiers. ${ }^{25}$ The archbishop of Canterbury had urged the government to put a stop to this scandal but Lloyd George and his secretary-mistress Frances Stevenson thought his attitude 'a piece of blatant hypocrisy'. ${ }^{26}$ Lloyd George consulted two leading free churchmen, the baptist J. H. Shakespeare and R. J. Campbell of the City Temple, both of whom he found 'very reasonable'. Further support came from the new Anglican paper The Challenge edited by Tissington Tatlow, secretary of the SCM, which held that 'the day is passed when the Church could insist on sacramental tests'. ${ }^{27}$ But with the expansion of the army the problems became too great to be left to the charities and in framing the naval and war pensions act of November I9IS the government did follow the archbishop's advice and prescribed different ways of meeting the needs of the two groups of women dependents. ${ }^{28}$

If drunken women were letting their husbands down, drunken workers were letting the rest of the country down. When nine thousand engineers on the Clyde went on unofficial strike for more pay in February 1915, it was the signal for a generalised attack on working class irresponsibility. ${ }^{29}$ At Bangor Lloyd George addressed a Sunday afternoon meeting of black-coated citizens 'most of whom had probably spent the morning in the tabernacles of dissent' ${ }^{30}$ In a speech rapturously received in free church circles, he asserted that 'drink is doing more damage in this war than all the German submarines put together' and specifically linked bad time-keeping and bad workmanship to over-indulgence in alcohol.

In fact the report which he later commissioned stated that no significant increase in drinking had occurred on the Clyde since the war began. ${ }^{31}$ Why then did Lloyd George believe that it had? Two days before making the Bangor speech the chancellor had discussed

${ }^{25}$ Violet Markham, Return Passage (London 1953) p 148.

${ }^{28}$ Bell p 750; [Lloyd George: $A$ Diary by Frances Stevenson, ed A. J. P.] Taylor (London 197I) p 6.

${ }^{27}$ Challenge II December 1914.

${ }^{28}$ Bell p 750.

${ }^{29}$ Walcer Kendall, The Revolutionary Movement in Britain 1900-21 (London 1969) cap 7 'Clydeside in Wartime'; [R. K.] Middlemas, [The Clydesiders: A Left-Wing Struggle for Parliamentary Power] (London 1965).

${ }^{30}$ Manchester Guardian I March igi 5.

31 Report of the Committee on Bad Time Keeping, Parliamentary Papers 1914-I6, LV 220 P 3, 24 . 
what he should say with Dr Alexander Whyte, the distinguished minister of Free St George's, Edinburgh and principal of New College. ${ }^{32}$ It seems likely that he was the source of Lloyd George's information. Dr and Mrs Whyte were in London for a few days and spent most of their time, as Mrs Whyte put it, in an attempt to get a little forward with our drink difficulties in Scotland', ${ }^{33}$ Their son was liberal MP for Perth and parliamentary private secretary to the first lord of the admiralty Winston Churchill, who was at that time member for Dundee. They thus had access to the highest political and ecclesiastical circles and were evidently lobbying vociferously on behalf of the demands of the Scottish temperance movement.

This movement had been reinforced enormously by the experiences of war. As in England, concern had been aroused by the treating of soldiers and the alleged dissipations of soldiers' wives. ${ }^{34}$ Glasgow provided the driving power of the movement, and looked naturally for help to the conservative leader Andrew Bonar Law, himself formerly a Glasgow iron-merchant, the son of a presbyterian manse, and a teetotaller. Frank Knight, minister of Hillhead united free church appealed to both Law and his predecessor A. J. Balfour in December $1914 .^{35}$ In January I9Is Sir Joseph Maclay, a Glasgow shipowner, urged Bonar Law to assure the government that drastic measures would not be opposed. Maclay pointed to the breadth of support for action in Scotland: all the parties and all the churches wanted wartime prohibition. Amongst the recent converts he mentioned Norman Maclean, minister of the wealthy and fashionable Park church ("and you know that that Church is not famed for Temperance'). ${ }^{36}$ Norman Maclean was a romantic highlander, florid and fervent in both the pulpit and the press. In an article in The Scotsman, re-published in his book The Great Discovery, he deplored the insufficient steps being taken to protect the homes of 'the men who are baring their breasts to the arrows, standing between us and death':

When they come back, war-worn, to what will they return? To homes in which the fires are extinguished, the candles burnt down to the socket; the cupboards bare, the children famished and

32 Daily News I March 1915; G. F. Barbour, The Life of Alexander Whyte, D.D. (London 1925) p 573 .

${ }^{23}$ SCM A[rchives] (consulted at Annandale) Jane Whyte-T. Tatlow I7 March 1915.

as On soldiers see the discussion of Lord Tullibardine's letter to members of the Perth UF presbytery about the Scottish Horse, GH 7 January 1915.

${ }^{35}$ BM Bonar Law MS 35/4/42 G. A. F. Knight-A. Bonar Law 16 December 1914.

${ }^{36}$ Ibid $36 / 1 / 17$ J. P. Maclay-A. Bonar Law 12 January 1915. 


\section{Drink and disestablishment in the first world war}

neglected? Is that to be the guerdon of their sacrifice; is it for that that they have gone down into hell? Surely it cannot be for that! A wave has passed over us, raising us to the realisation of the higher values of things. Words live for us now which were dead yesterday. A beam of light has fallen into the chamber of imagery, and the word Temperance has risen from the couch on which it lay dying, and it claims us for its own. Through it we can make the world know that we are worth fighting for - worth that the young, the strong, and the brave should take everything they hold dear - their ideals, their love, their little children unborn and throw them into the trench, and there give themselves and their dreams to death for us. We must see to it that we are worthy of the sacrifice. ${ }^{37}$

Of the strength of feeling in Scotland as a whole, and Glasgow in particular, there were many manifestations. Prohibition was even advocated at a meeting of the Glasgow Catholic Socialist Society in January I9Is (though not all the members agreed) ${ }^{38}$ and in February the reverend Colin M. Gibbs persuaded the Glasgow parish council to ask the government for stronger restrictions to protect women. A week later speeches by Knight and professor J. W. Gregory advocating wartime prohibition were published as a pamphlet and reached a large circulation. The Spectator saw the pamphlet as evidence of the great movement of opinion in Scotland and expressed sympathy. ${ }^{39}$ On 22 February while the Clyde strike was still solid, a large meeting for wartime prohibition was held in the Merchants' Hall, Glasgow, and decided to send deputations to the prime minister and leader of the opposition. The meeting was a gathering of the business and academic communities, presided over by a retired professor of civil engineering, and attended by prominent shipowners and shipbuilders. A letter was read from Alexander Gracie, chairman of Fairfields shipbuilding company which complained of excessive drinking by his workers. ${ }^{40} \mathrm{~A}$ fortmight later the secretary of the Scottish temperance league stirred the pot further by remarking:

\footnotetext{
${ }^{37}$ N. Maclean, The Great Discovery (Glasgow I9I5) pp I48 seq. For another example of how Maclean's rhetoric could outrun his judgement see [Stuart] Mews, 'Kikuyu and Edinburgh [: the interaction of attitudes to two conferences'], SCH 7 (1971) pp 345-59.

${ }^{38}$ Scottish Prohibitionist 2 January I915. On the society see Middlemas pp 36-40; Patrick J. Doyle, 'Religion, Politics and the Catholic Working Class', New Blackfriars, May $1973 \mathrm{pp} 218-25$.

${ }^{30} \mathrm{~J}$. W. Gregory and G. A. Frank Knight, A Plea for Prohibition during the War (Glasgow I9I5); Spectator I3 February I9Is.

${ }^{40} \mathrm{GH} 23$ February 1915.
} 
In the widespread agitation for increased wages being waged in the shipbuilding industry, I somerimes wonder if either master or men have fully realized the great economic waste being caused by indulgence in strong drink. ${ }^{41}$

On the same day the distinguished Glasgow theologian James Denney informed Robertson Nicoll, editor of the British Weekly that a memorial to the prime minister to stop the sale of distilled liquors in Scotland during the war is having extraordinary support. Everyone to whom it is submitted seems willing to sign it - especially employers of labour, irrespective of party connections'. ${ }^{42}$ The Scottish press reported all these developments and Mrs White was hardly divulging any secrets when she told Tissington Tatlow shortly after her visit to London and her husband's chat with Lloyd George, 'privately we hear that the reports from some of the ship-building yards in the West are so bad that there is bound to be action'. ${ }^{43}$

Despite the chancellor's bold words at Bangor, which built up the hopes of the temperance lobby, he was to take no action whatever for several weeks. When he did move it was in such a flurry of frenetic activity that some explanation apart from the earnest petitions of a slightly panicky Scottish bourgeoisie is required. The true explanation requires a shift of scene: from urban Glasgow with all the social problems and political unrest of the modern metropolis to rural Wales with its more traditional and possibly more vicious ecclesiastical and political divisions.

On 9 March I9Is the government had introduced into the house of lords without notice or consultation with its supporters, a bill to delay the disestablishment and disendowment of the Welsh church until six months after the end of the war." It had passed through all its stages in a single day and on the very next day was brought before the commons. But for the pressure of government business, the Welsh church disestablishment act, the goal of a generation of nonconformist political effort would in the space of forty eight hours have been placed in jeopardy. For the bill aroused in Welsh nonconformist minds the great fear that if the election which had to be held immediately after the war were to install a conservative government

11 Ibid 8 March 1915.

42 J. Denney-W. R. Nicoll 8 March 1915, Letters of Principal James Denney to $W$.

Robertson Nicoll 1893-1917, ed W. R. Nicoll (London 1920) p 245.

is SCMA J. Whyte-T. Tatlow 7 March 1915.

4 [P. M. H.] Bell, Disestablishment [in Ireland and Wales] (London 1969) p 300. 


\section{Drink and disestablishment in the first world war}

in office, there would be nothing to prevent it from repealing an act which had not even begun to take effect.

Welsh disestablishment was the greatest nonconformist legislative victorv of the twentieth century but was little enough return for the energy and enthusiasm devoted to the liberal cause by free churchmen. ${ }^{45}$ Now even this triumph looked as if it might be snatched away and changing circumstances suggested that any ground lost now would be unlikely to be re-captured later. In Wales despite the revival of I904-5. itself a defensive reaction to the threat of alien cultural forces, ${ }^{46}$ the chapels were increasingly conscious of declining power, especially in the industrial areas of the south. In the nineteenth century nonconformity had been 'the most important link between rural and industrial Wales', ${ }^{47}$ but the depopulation of the rural areas and the movement into the mining valleys of workers from England, Scotland, and Ireland destroyed the shared values of town and country. ${ }^{48}$ Welshspeaking nonconformity was being turned into a rural religion with a set of traditional values which seemed out of place in the modern world.

In his autobiography Goronwy Rees - aged six in I9IS - has described the Aberystwyth of his boyhood. It was a small country town with an astonishing number of chapels and churches: 'On my way to school every day I passed a Salem, a Shiloh, a Tabernacle, a Bethel, and a Moriah; it was like taking a walk through the Middle East'. His father was a Calvinistic methodist minister 'and this made him a person of considerable importance in the town':

Ours was a theocratic society, ruled by priests and elders; they formed a sort of unofficial Sanhedrin which exercised an absolute dictatorship over the morals and behaviour of the town. ${ }^{49}$

In the smug, claustrophobic society of small towns like Aberystwyth disestablishment mattered. It had been achieved in the very nick of time. It was the last act before the curtain finally fell on a world which we have lost.

The outbreak of war in 1914 provided a further challenge both to

4 On free church disillusionment with politics: Stuart Mews, 'Puritanicalism, Sport and Race: A Symbolic Crusade of 1911', SCH 8 (1971) pp 303-31; Stephen Koss, Nonconformity in Modern British Politics (London 1975) cap 5.

${ }^{46}$ C. R. Williams, 'The Welsh Religious Revival I904-5', British Journal of Sociology 3 (London I952) p 242.

17 David Williams, A History of Modern Wales (London 1950) p 246.

${ }^{19} \mathrm{~J}$. Vyrnwy Morgan, The War and Wales (London 1916) p 282.

${ }^{4}$ Goronwy Rees, A Bundle of Sensations (London I960) pp I9 seq. 
nonconformist assumptions about human nature and to nonconformist claims in Wales. The chief justification for disestablishment was the overwhelming numerical preponderance of chapel-goers over churchgoers. The records of enlistments in the army, however, suggested either that the figures presented in the royal commission had been fudged or that nonconformists were not pulling their weight in the defence of their country. ${ }^{50}$ Robert Graves claimed that the reason Welsh-speakers were such rarities in the Royal Welch Regiment was because 'the chapels held soldiering to be sinful, and in Merioneth, the chapels had the last word. Prayers were offered for me by the chapels not because of the physical dangers I would run in France, but because of the moral dangers threatening me at home'. ${ }^{51}$ Whatever the truth of these claims and impressions, the war created a situation in which the standing of the established church was enormously enhanced, while Welsh nonconformity could too easily be made to look mean, petty and unpatriotic. Moreover these same pressures were simultaneously undermining English support for Welsh nonconformist claims. 'What seems now to be desired', commented the Anglican Guardian of English nonconformity, "is not so much the disestablishment of one communion, but the equal establishment of all'. Though free churchmen would not admit it, 'the war is only one of the links which have bound them more and more closely to the state' ${ }^{\mathbf{5 2}}$

The schizoid nature of the free church mind at this time was well illustrated when its national council met in Manchester on the day after the introduction of the bill. It was bitterly denounced, mainly by speakers from Wales, but this demonstration of wrath had to be cut short so that the delegates could get to the cathedral in time for an ecumenical service arranged for them by the dean. In Cambridge T. R. Glover, fellow of St John's and a baptist stalwart, felt 'upset' at the government's 'surrender . . . after all that has been done'. ${ }^{53}$ But Robertson Nicoll was 'furious' at what he saw as a 'betrayal of the Dissenters'. His British Weekly noting the 'general amazement and consternation' called for 'unrelenting opposition' ${ }^{54}$ On this occasion

${ }^{50}$ The official statistics of rcligious affiliation in the 38 th division from Wales in August I9I 6 were $63 \%$ church of England, $32 \%$ nonconformist, $6 \%$ Roman catholic. For the difficulties this caused in the provision of chaplains see Stuart Mews, 'Religion and English Society in the First World War' (unpubl Cambridge PhD thesis 1973) PP 196-9.

${ }^{31}$ Robert Graves, Goodbye To All That (London 1966) pp 70 seq.

s2 Guardian 25 March I915.

${ }^{\text {ss }}$ Diary of T. R. Glover (courtesy of Miss A. Glover) ro March 1915.

${ }^{34}$ [Lord] Riddell's [War] Diary [1914-18] (London I933) ro March r9rs p 68; B[ritish] $W[e e k l y]$ i I March igis. 


\section{Drink and disestablishment in the first world war}

Lloyd George's 'usual intuition ... seems to have failed him', divined Beriah Evans, a journalist once editor of one of the chancellor's Welsh papers but increasingly distrustful of his former master's commitment to Welsh national interests. 'This was the last straw', Evans wrote, 'it overstrained the patience of even the submissive Welsh members'. In response to a great wave of resentment which swept through Welsh nonconformity, the Welsh parliamentary party 'for once took a bold and determined stand against Mr Lloyd George and the government'. ${ }^{55}$

When the bill came up again in the commons on Is March Lloyd George tried to talk his old colleagues round. Once again the business was badly mismanaged. Immediately preceding it on the order paper was a naval bill sent down from the house of lords. Unfortunately it included an amendment moved by the archbishop of Canterbury to make it illegal for a sailor's marriage to take place in a nonconformist chapel if the banns had been read in an Anglican church. At the very mention of the archbishop's name 'loud ironic cheers arose' and the debate had to be hastily adjourned. After this unpromising beginning the house turned its attention to the Welsh church bill. Lord Robert Cecil spoke 'gently as a cooing dove', noted the Daily News, but any eirenic atmosphere created was soon dispelled when Ormsby Gore began taunting Sir Alfred Mond, the German-Jewish member for Swansea: "What has this representative of Welsh nonconformity done for the British army?' 56 Now the fat was in the fire and the house witnessed 'a strange, almost grotesque revival of the Welsh Church controversy in the midst of war.' ${ }^{\prime} 7$ Even Lloyd George with all his debating skill failed to make any impression. "At one point his voice broke under stress of his emotions', reported the British Weekly 'and he claimed the indulgence of the House on the ground that the matter vitally affected him as he counted the good opinion of his native country Wales more than anybody in the whole world'. 58 'Went for the Welsh MPs' he wrote home to his wife, 'They are a poor lot of hounds. They thoroughly misrepresent the Bill. It is a very small

${ }^{55}$ [Beriah] Evans, [The Life Romance of Lloyd George] (London nd-I9Is?) pp 124, 123. Eight years earlier Lloyd George had written in the margin of a letter to Robertson Nicoll: " $B$ " is the jobbing journalist I refer to in my interview as a manufacturer of revolt copy - his full name is Beriah G. Evans', National Library of Scotland MS 5666 D. Lloyd George-W. R. Nicoll 6 October 1907; Kenneth O. Morgan, Wales in British Politics 1868-1922 (Cardiff 1970) p $102 \mathrm{n}$.

so Daily News 16 March 1915.

${ }^{67}$ Bell, Disestablishment p 300.

${ }^{88} \mathrm{BW}$ I 8 March 19Is. 
concession for the sake of Unity'. ${ }^{59}$ One of Lloyd George's colleagues claimed that the general feeling of the house was that this was 'one of the pluckiest speeches' he had ever made, ${ }^{60}$ but it did not persuade the Welsh members and the virulence of their opposition caused Asquith to defer the vote and promise a further debate. Nor did Lloyd George convince the leaders of the disestablishment movement outside the house. 'What a gas-bag speech George made on Monday night!' wrote John Massie, president of the Liberation Society and congregational minister, formerly a Mansfield college tutor and briefly a liberal MP. Massie was thoroughly disenchanted with Lloyd George. Behind the postponement proposal he saw the sinister hand of the church tories who, he claimed, had already persuaded Sir Henry Lunn ('the self-advertising Lunn') to petition for the removal of the disendowment clauses. 'George's trapping of the P.M. is just enabling the Robert Cecil lot to step back for a final leap'. ${ }^{61}$

The Robert Cecil 'lot' did indeed want to take the final leap and repeal the act in its entirety but Massie's reading of the situation was an oversimplification. On the church side there were three significant groups which did not always pull together. There were the English bishops, the bishops in Wales, and those Anglicans in parliament who had a special interest in this particular cause. Unlike the other two groups, the church tories were conscious of both the ecclesiastical and political dimensions of the question. They wanted not only to save the Welsh church but also to bring down the liberal government, and they knew that in some areas it was still possible to work up a politically advantageous agitation on the theme of church defence. Archbishop Lang had been immensely impressed by the great demonstration against the Welsh church bill held in York in the summer of 1913 . The minster had been crowded from end to end and afterwards the market place packed with what is said to have been 'the largest crowd seen there for more than a generation'. ${ }^{62}$ In 1914 a report on liberal electoral prospects in the Howdenshire division of the east riding of Yorkshire stated that the country clergy were exerting themselves to 'poison the minds' of their flocks. In several villages it was reported

s2 D.-M. Lloyd George Is March 1915, Lloyd George Family Letters 1885-1936, ed Kenneth O. Morgan (Cardiff/London 1973) p i76.

${ }^{\circ}$ [Christopher] Addison, [Four and a Half Years, I] (London I934) p 70.

1 N[ational] L[ibrary of] W[ales] Griffith MS $468 \mathrm{~J}$. Massie-E. Griffith 19 March I9I5.

02 [Hickleton,] Halifax MS A4.259 C. G. Lang-Lord Halifax 26 June igr 3. 


\section{Drink and disestablishment in the first world war}

that 'our vicar says' that the liberals were killing religion in Wales 'and shutting up all the churches'. ${ }^{63}$

Once the bill had been passed, some English bishops like Edward Talbot of Winchester, were prepared to accept it but wanted to work for minor adjustments to enable the new body to function efficiently, but the Welsh bishops encouraged by the church tories to believe that total repeal was just around the corner, were reluctant to acquiesce or compromise. ${ }^{64}$ Bishop Talbot had been dissuaded from writing to The Times in October $19 \mathrm{I} 4$ by Lord Robert Cecil but he did write privately to Lloyd George about the financial difficulties which would be caused by the gradual removal of the church's pre-1662 endowments at a time when wartime conditions made it impossible to build up a capital fund to take their place. In all his dealings about the Welsh church Talbot stressed the need to overcome the divisions of the past. He told Lord Hugh Cecil that he was 'not just after pickings for the Church' but wanted to demonstrate the new temper arising through co-operation in the war'. Though a strict high churchman Talbot was an enthusiast for the ideal of church unity, a conviction which had been strengthened by his connections with the student Christian movement and the Edinburgh missionary conference of I9IO. In January igis he did write to The Times along these lines and was supported by the veteran nonconformist minister Arnold Thomas of Bristol. ${ }^{65}$ Meanwhile Sir Henry Lunn, a prominent Wesleyan who supported disestablishment but not disendowment, had offered to organise a petition of English nonconformists if the Cecils and their friends would help to defray the costs. The Cecils were not overenthusiastic and sent him off to the ECU office where he was told that it was "quite impossible to raise $\$ 200$ just now from any rich man in the Church of England'. Lunn persevered and winkled out enough small subscriptions to proceed. The duke of Devonshire contributed $f_{25}$ but expressed his doubts to Lord Hugh Cecil about whether the rest of the bill would be repealed if disendowment was deleted. ${ }^{66}$

63 [House of Lords Library] Lloyd George MS: 'Report on Howdenshire Division' I2 May 1914. See also Newcastle Daily Journal 24 March 1914.

44 Halifax MS A4.267 Lord Salisbury-Lord Halifax is August 1914.

os Bodleian Selborne MS 90/II Lord Robert Cecil-Lord Selborne 18 August 19I4; Lloyd George MS C/1 r/2/4 E. S. Talbot-D. Lloyd George 18 August 1914; Hatfield MS Qui 18/16i E. S. Talbot-Lord Hugh Cecil 30 December 1914; Mews, 'Kikuyu and Edinburgh' pp 348 seq; Times I2 January igis.

60 Hatfield MS Qui 18/129 Sir H. Lunn-Lord H. Cecil 4 December, Qui 18/150 LunnCecil 17 December; Qui 18/153 Lunn-Cecil 2s December 1914; Qui 18/159 Duke 
To head off this possibility and take advantage of the more favourable climate created by Lunn's petition, the duke proposed in the house of lords on 9 January I9Is that the act as a whole should be postponed until the end of the war. Government ministers met the unionist leaders and agreed that if the duke would withdraw his bill, they would introduce their own. The government's bill was based on a memorandum submitted to Asquith by the home secretary Reginald McKenna. He later explained to the Welsh nonconformist members when they complained about the lack of consultation that it had never occurred to him that the prime minister would act so quickly, but his critics noted that 'there is no question that McKenna has behaved very cryptically' and 'his anger was not impressive'. ${ }^{67}$

Lloyd George blamed McKenna for muddling the business but there was a widespread belief in Wales that the chancellor must have known what was going on. Even such an old friend as John Williams of Brynsiencyn, the greatest Welsh preacher of the day, who had stood by Lloyd George during the Marconi scandal, now described the bill (in Welsh) as 'an inexcusable betrayal of Wales'; Lloyd George would have to produce something better than another soothing speech at the pavilion (his usual stamping ground in his constituency) to explain away this treachery. ${ }^{68}$ The executive of the Welsh national liberal association was due to meet at Llandrindod Wells on 30 March and there was no doubt about the main item on the agenda. Of course Lloyd George had been in hot water before, but this time it had reached boiling point. Could he escape unscathed yet again? 'I earnestly hope that George will not bamboozle the Welsh Party', wrote John Massie none too confidently. 'He will play low down to do it. But we trust you to stand to your guns'. ${ }^{69}$

In the breathing space between the commons debate on Is March and the Welsh executive on 30 March Lloyd George worked ferociously. Supporters of the government pointed out that there was one

of Devonshire-Lord H. Cecil 28 December I914. See also Sir Henry S. Lunn, Chapters From My Life (London 1918) cap 22.

7 Davidson MS, 'Memorandum on the Welsh Church Question', 1918; A. G. Edwards, Archbishop of Wales, Memories (London 1927) cap 13; Eluned E. Owen, The Later Life of Bishop Owen. A Son of Wales (Llandyssul 196I) cap 21; Sir Almeric Fitzroy, Memoirs 2 (London nd) pp 586, 590.

${ }^{68}$ In fact Lloyd George denied any knowledge of what had been happening: The Political Diaries of C. P. Scott 1911-28, ed Trevor Wilson (London 1970) p 119; Holyhead Mail 8 August 1913; Griffith MS 503 : John Williams-Ellis Griffith 17 March 1915.

${ }^{\circ 0}$ Griffith MS $468 \mathrm{~J}$. Massie-E. Griffith 19 March 1915. 


\section{Drink and disestablishment in the first world war}

issue which outran the disestablishment question in the chapeldominated communities of nonconformist Wales - the drink question: 'I feel that if you can see your way to take strong action in regard to the licensing question, really recognising the advanced condition of opinion in Wales', advised one Liberal MP, 'you would do a great deal to create an atmosphere in which the Church controversy would dwindle greatly alike in difficulty and acrimony'. ${ }^{70}$ Tackling the drink question would not only salve the nonconformist conscience but might also be a means of vindicating the honour of nonconformist Wales. Speakers at Welsh recruiting rallies were trying hard to sell a new image of the army. "The Army was a profession they could now adopt with dignity', said Sir Edward Pryse at Aberystwyth in 1914; 'it was composed of gallant young men, and the old vice of drunkenness had been done away with practically, and the bulk of the men were now teetotallers'. ${ }^{71}$ If Lloyd George could give substance to that illusion he could yet be the saviour of Wales.

The temperance card was clearly the one to play, but Lloyd George rightly sensed that words alone were not enough. In the field of temperance reform no proposals were practicable which were not acceptable to the trades unions. On 17 March he took advantage of a meeting with union representatives to secure their agreement for new restrictions if two conditions were met: there had to be sufficient evidence to justify the proposals, and they should be applied equally to all classes. Having got so far, the chancellor's next task was to outline proposals, manufacture the evidence to justify them, and to awaken public opinion in support of them.

On the same day that Lloyd George was coaxing the trades unionists into accepting further controls on drink Mrs Jane Whyte was once again busily lobbying on behalf of the Scottish temperance movement. She wrote to Tissington Tatlow passing on a complaint she had several times heard in Scotland: 'why does the Church of England do nothing?' She also persuaded J. $\mathrm{H}$. Oldham, secretary of the continuation committee of the Edinburgh missionary conference of I9Io to approach the bishop of Winchester. He told Talbot that when the prime minister had received the petition for prohibition from Glasgow he had said that firm action needed the strong backing of public opinion. Oldham had been shown a letter from the government chief whip forecasting bold measures from Lloyd George if he feels that

${ }^{70} \mathrm{NLW}$ E. T. John MS, E. T. John-R. McKenna 22 March Igr s.

"Newspaper cutting in Griffith MS 149. 
public opinion will support him'. Two moulders of public opinion in the tory press, J. L. Garvin and Lord Northcliffe, were prepared to support a popular agitation if it once got underway. Unfortunately 'the Liberal press has been very half-hearted in its support of what Lloyd George said, and . . . it is not possible for the Tory press under these circumstances to initiate a campaign.' It was obvious from Lloyd George's trades union meeting the previous day that the government was angling for the support of labour. 'I cannot help thinking, however, that knowledge that the Church was with them would greatly strengthen their hands.' Tatlow also wrote to Talbot to reinforce Oldham's plea but it fell on stony ground. The bishop of Winchester had been staying with the archbishop of Canterbury and learned that he had already discussed the matter with the prime minister. Asquith had characteristically assured him that there was no need to rouse public opinion. But then Asquith never did pay much attention to popular outbursts, and was even less likely to be influenced by a storm got up in favour of proposals which he felt were radically unsound. Oldham had wanted to avoid resurrecting the old teetotal versus antiteetotal arguments by resting his case solely on the claims of national efficiency. But Davidson and Talbot 'felt rather strongly that it is not the Church's special business to urge restrictions in the interests of war materials.' Moreover they agreed with Asquith that general measures which did not take into account local circumstances were unwise. But this was just the opposite of Oldham's opinion. Limitations only on munition areas implied a slur on the men involved. Why should not the west-end clubs accept the same limitations? 'After all this is a national affair. We don't want to pillory certain sections of the population but to submit to an act of national discipline'. This was also the view of William Temple, who was always rigorous on moral questions: he favoured total wartime prohibition as an act of national self-sacrifice. But though the archbishop was ready for personal selfsacrifice, he was not willing to advocate sacrifice by government decree. Nor did he take to Tatlow's suggestion that an interdenominational meeting should be called at Lambeth on the same lines as those called at the beginning of the war to thrash the matter out. ${ }^{72}$

Asquith, Davidson and Talbot were right to be sceptical of the breadth and spontaneity of the demands for new temperance legislation. In his private diary, Sir J. Herbert Lewis, a liberal and free church

"2 SCMA J. Whyte-T. Tatlow 17 March I9rs; J. H. Oldham-T. Tatlow I8 March I9IS; T. Tatlow-E. S. Talbot 22 March 1915; E. S. Talbot-T. Tatlow 26 March 19rs. 


\section{Drink and disestablishment in the first world war}

$\mathrm{MP}$, and lifelong disciple of Lloyd George, let the cat out of the bag about his master's methods. 'In his own astute way he worked up interviews and a press agitation to obtain the necessary driving power'. The grand climax came on 29 March, the very eve of the Llandrindod meeting, when a deputation of the shipbuilding employer's federation met the chancellor ('probably at his own instigation' noted Lewis) and requested total wartime prohibition 'We are fighting Germany, Austria and Drink', thundered Lloyd George in a speech which every member of the Welsh executive could read on the morning of their meeting, 'and, as far as I can see, the greatest of these deadly foes is Drink' ${ }^{73}$ The conversion of the shipbuilders to prohibition was impressive enough, but the chancellor had an even bigger rabbit yet to pull out of the hat.

On the same day that he met the shipbuilding employers, Lloyd George had carlier had an audience with king George V. According to the royal biographer Harold Nicolson, he had 'bustled into the King's audience room, his little arms swinging with excitement, his eyes flashing flame, his lower lip protruding with scorn of those who drank'. ${ }^{74}$ In the Bangor speech the chancellor had held up the example of czar Nicholas. He had been told that the royal example had been a major influence in making the prohibition of vodka acceptable in Russia. Now he told king George that it would be much easier to apply coercive measures if he took the lead by announcing that he proposed to be a total abstainer during the War'. 'He was impressed', Lloyd George reported to his uncle, adding later, 'whilst I have been engaged all day on this gigantic problem I suppose my Welsh teetotal friends are engaged in nagging at me in Rhyl. God help the country that is under their care..$^{75}$

Immediately after the shipbuilders had departed the chancellor sent an account of the meeting to Buckingham palace in which he stressed that the situation was deteriorating and that any remedy must apply to all classes of the community: 'it was most important that the workmen should not imagine that drink was to be forbidden them whilst the rich were to be permitted still to indulge' ${ }^{76}$ Lord Stamfordham replied immediately on the king's behalf:

${ }^{39}$ [NL W J. H.] Lewis [MS 231], Diary of 23 October I9r5; 30 March igrs. Hazlehurst p 212; Times 3o March igrs.

${ }^{74}$ Sir Harold Nicholson, King George the Fifth. His Life and Reign (London 1952) p 261.

78 William George, My Brother and I (London 1958) p 249.

${ }^{20} \mathrm{R}$ [oyal] A[rchives] GV Q762/12 D. Lloyd George-Lord Stamfordham 29 March 1915. 
I am to add that if it be deemed advisable the king will be prepared to set the example by giving up all alcoholic liquors himself and issuing orders against its consumption in the Royal Household, so that no difference shall be made so far as His Majesty is concerned between the treatment of rich and poor in this question. ${ }^{77}$

Lloyd George read the king's letter to the cabinet and according to his reply to the palace 'they felt that if the King took the lead in the matter the nation would follow him' ${ }^{78}$ However the prime minister did not share this optimistic assessment: 'the country will not stand prohibition', he insisted, 'it isn't feasible'. Frances Stevenson suggested the real reason was that he himself was not prepared 'to give up his wine and whisky'. Later that day he sent for the chancellor and said, 'A bout that King thing - I would not play that card yet if I were you'. Lloyd George then explained that even under prohibition it would always be possible to get alcoholic drinks with a doctor's certificate. This seemed to lift a burden from the prime minister's mind and he gave his permission for the king's letter to be sent to the press. ${ }^{79}$

The king's pledge, as it came to be known was the high point of Lloyd George's campaign. It horrified the archbishop of Canterbury. Randall Davidson's career owed much to the patronage of the court. As dean of Windsor he had put that career at some risk in an attempt to save queen Victoria from looking ridiculous when he opposed the publication of a further volume of her highland diaries. The possibility of her grandson now being made into a laughing-stock troubled the archbishop deeply. He was also somewhat embarrassed. Lloyd George was asking the heads of the professions, the bar, medicine and the church, to follow the king's lead and urge their colleagues and subordinates to join them. But the archbishop of Canterbury had already ruled out such action. Shortly after the Bangor speech, a suggestion had been made in The Times by Sir Edward Clarke, president of the national church league, and a former conservative law officer, that the Anglican clergy should make a great united act of patriotic self-denial by pledging themselves to wartime abstinence. The proposal was applauded by the bishops of Croydon and Durham but briskly denounced by the dean of Durham, Hensley Henson, as both irrational and ineffective. The idea had been similarly dismissed

${ }^{77}$ RA GV Q712/14 Lord Stamfordham-D. Lloyd George 30 March I9Is.

${ }^{38} \mathrm{RA}$ GV Q762/15 D. Lloyd George-Lord Stamfordham 30 March 1915.

${ }^{30}$ Taylor p 39. 


\section{Drink and disestablishment in the first world war}

by the archbishop because 'the fact of every bishop, priest, and deacon in the country becoming a teetotaller would not in the smallest degree impress the popular imagination.' ${ }^{80} \mathrm{How}$, then, would he react to the king's request? His difficulty was enhanced by a profound conviction that the king had been both misled and misunderstood. The royal message was conditional - 'if it be deemed advisable' - and was intended to demonstrate that the king would personally share any restrictions imposed by the government upon his subjects. But the message was being interpreted to mean that the king had already given up alcohol which he had not. To avoid the possibility of accusations of hypocrisy, the king now gave orders that no alcoholic drinks were to be served in the royal household. At Windsor castle the servants decorated the cellar-door with black crepe. ${ }^{81}$ Two former prime ministers Rosebery and Balfour, both thought that the king had been disgracefully treated and the archbishop tried to shicld him from further exploitation. The archbishop was not very receptive to the idea that the king should be invited to attend temperance meetings and that further declarations in favour of prohibition should be issued from Buckingham palace. The king's secretary thanked him for suggesting that 'no notice' be taken of the bishop of Willesden's letter. ${ }^{82}$ But in response to a request from the king, Davidson did try to issue an appeal signed by the leaders of all the churches, though cardinal Bourne took some time before he agreed to add his name.

The secretary of the free church council, F. B. Meyer, wrote to ministers suggesting a king's pledge Sunday on which they could urge their congregations to follow the royal lcad, but in at least one Lancashire town this was regarded as quite superfluous: "We should be wasting our effort inasmuch as the vast majority of our folk are pledged abstainers already'. The Tablet testified to Roman catholic scepticism about the pledge.

A professor in the seclusion of the Athenaeum, may give up his accustomed pint of claret, and a clergyman in his lonely parsonage may deny himself his glass of whisky-and-water, but in what possible way can these changes serve for an example to the workmen on the Clyde?

${ }^{80}$ RA GV Q762/19 D. Lloyd George-Lord Stamfordham I April 1915; Davidson MS G. K. A. Bell-R. T. Davidson I April I9Is; Lord Stamfordham-R. T. Davidson 6 April I9I5; Times 5, 6, 8, I9 March 1915; Guardian 25 March Igrs.

81 [Durham Chapter Library MS, Diary of H. H.] Henson 29 April I9I 5.

82 Davidson MS R. T. Davidson-C. F. Harford Io April; ibid Lord StamfordhamR. T. Davidson I April I915. 
There seemed to be too little connection between the suggested privation and the public example. ${ }^{83}$

That was precisely the view of Hensley Henson. 'This is a strange proceeding', he observed when he read of the king's pledge, 'and creates a situation of some difficulty for the loyal subject who dissents from the royal example':

What ought the Dean of Durham to do? All that loyalty rightly demands he must take the lead in doing, but does a self-respecting loyalty require him to admit the governing lead of the King's example within his own house? Does not his duty rather require him publicly to differentiate loyalty from such servility? And is not the consideration the more cogent in his case since the King is the author of 'preferment', and any demonstration of independence on his part may affect adversely the Royal mind?

Two days later Henson records: 'We drank champagne in spite of the King's example'. 84

A fortnight later Henson was in London to be invested as grand chaplain of a masonic order. He spent some time at the Athenaeum where he found everyone drinking wine, and bumped into Lord Halifax, a long-standing opponent on almost every conceivable ecclesiastical question. But on this matter they were united; indeed Halifax was quite adamant: ' $I$ shall not give up my beer - It ought never to have got the encouragement it has from the archbishop of Canterbury'. Halifax could not, however, control the tables of his hosts. The warden of Keble, to his delight, continued to serve alcohol but archbishop Lang offered lemonade and archbishop Davidson could only manage water. On his next visit to Lambeth palace Halifax took with him a secret supply of whisky, and after retiring to his bedroom for the night began a small drinking-party with a fellow guest. All was in full swing when a knock on the door revealed an embarrassed archbishop seeking a few final words with his equally embarrassed noble guest. ${ }^{85}$

In the week before the king made his decision Lloyd George was attempting to represent the Welsh church postponement bill to his fellow country-men as a bargaining counter which could be used to prise temperance reform from an unwilling tory party. John Williams

${ }^{88}$ Burnley News 24 April I915, but for a more optimistic assessment see E. K. H. Jordan Free Church Unity (London 1956) p 147; Tablet ro April 1915.

${ }^{84}$ Henson 6 April rigr.

ss Ibid 29 April I9rs; Halifax MS A.40214 Lord Halifax-H. W. Hill 7 April igrs; Lockhart pp 237-8. 


\section{Drink and disestablishment in the first world war}

of Brynsiencyn was invited to II Downing Street on 24 March and told that a new licensing bill could be got through because the brewers could no longer count on conservative support. But he was warned, if the Welsh postponement measure were to be withdrawn, the tories would say " Very well, have things your own way, but you give way to your friends, we must give way to our friends" and goodbye to the best chance of carrying Temperance reform we have had in our generation.' ${ }^{86}$ It was this argument which Herbert Lewis presented at the Llandrindod Wells meeting on Lloyd George's behalf. It is a measure of the force of what Beriah Evans called 'such subterranean rumblings as portended an earthquake' that despite the Welsh wizard's earnest attempts to shift the scenery of the political stage, a decision was taken to oppose the postponement bill, a decision which was to result in July in its withdrawal. ${ }^{87}$

The decision was as much a vote of no confidence in Lloyd George as a revolt against the government. It was now even more vital for the chancellor to put his own personal stamp on some major measure of liquor control if his rocking throne in Wales was to be steadied. In his view the refusal of the house of commons to follow the royal gesture by closing its bars doomed the voluntary approach and some form of state intervention was unavoidable.

Lloyd George called the bishop of Lincoln to the treasury on 12 April and outlined to him a drastic solution. He wanted to nationalise the pubs and breweries and to prohibit altogether the sale of spirits. ${ }^{88}$ He believed that he could carry this plan through parliament because he had the acquiescence of the brewers and the conservative leaders. Unfortunately he had not taken sufficient account of the sectarian divisions of the temperance movement and of the absolute refusal of some of its most influential leaders to countenance state purchase in any shape or form. The bishop of Lincoln, when mesmerised by Lloyd George had seen state purchase as a step towards the obtaining of local veto, but his friends in the United Kingdom Alliance soon convinced him that he was mistaken and should come out in opposition.

The UKA has been described as 'essentially a protesting body' which 'conceived of prohibition in millenial terms' ${ }^{89}$ The tenacity with which

\footnotetext{
${ }^{80}$ Lewis 24 March r915.

${ }^{87}$ Evans p 220; Lewis 30 March 19r 5; Bell, Disestablishment p 301.

${ }^{88}$ Hicks 12 April 1915.

${ }^{89}$ Brian Harrison, Drink and the Victorians. The Temperance Question In England 1815-72 (London 1971) pp 375, 372.
} 
the more extreme wing of the temperance movement held to its single-minded and narrow objectives, together with their defective political sense, made it unlikely that they would accept any halfmeasures; indeed they were likely to be more hostile to temperance plans which diverged from their own pet schemes.

'A powerful section of temperance advocates were up in arms against the abhorrent suggestion that the State should sully its soul by becoming the manufacturer and distributor of alcoholic poison', recalled Lloyd George. "The conscience of the devotee is an eccentric thing and argument never converts but only exasperates a true believer. The resistance of this section grew.' ${ }^{\text {'0 }}$ Leaflets headed 'Lloyd George, Publican' were produced by some teetotal fanatics, and something of the flavour of the UKA's political style can be ascertained from its secretary, G. B. Wilson's address, to the free church council in the summer of I9I 5 . Even if state purchase were to halve the consumption of drink it must be resisted. Under nationalisation it will be your hands that ... pass the drink into the hands of your brother or sister trembling with eager unholy excitement for the deadly draught. . . All these ruined souls will be your servants for whom you must answer to Almighty God!' To accept such a scheme would be to abandon hope just when 'the promised land lies before us.' ${ }^{1}$

The churches were divided in their attitude. When rumours were still flying about the nature of the proposals to be put to parliament Anglican opinion seemed to veer towards state purchase which was supported by the convocation of York. Free church opinion, however, was fragmented and the council's general committee could only produce an anaemic resolution which avoided favouring any particular scheme. The president of the free church council, Sir Joseph Compton Rickett, a liberal MP and congregationalist layman, was bitterly criticised for making several speeches in favour of nationalisation and against prohibition. The president of the UKA Leif Jones, a liberal $\mathrm{MP}$ also and son of a Welsh congregational minister, was horrified to observe the free church president turning 'from advocating the disestablishment and disendowment of the church in order to preach to the country the establishment and endowment of the liquor trade'. ${ }^{92}$

${ }^{90}$ [D.] Lloyd George, [War Memoirs, I] (L ondon 1934) p 197.

${ }^{91}$ Quoted in Norman Longmate, The Water Drinkers (London 1968) p 267.

${ }^{08}$ Manchester Guardian 22, 29 April 1915; F. A. Iremonger, William Temple (London 1948) p I79; national free church council minutes of general committee no 9, II June 1915; Leif Jones, Why Leave the Straight Road? A Warning to Temperance Reformers (London 1915) P 3. 


\section{Drink and disestablishment in the first world war}

The determination of the UKA to campaign actively against Lloyd George's plan provided Asquith with good grounds for killing it. The UKA secretary claimed that the announcement of the movement's opposition at a crucial moment in the cabinet discussion was a major factor in the abandonment of the scheme: 'they threatened the most extreme action in the House of Commons', noted Herbert Lewis. According to Lloyd George the prime minister 'feared serious trouble inside the party. ${ }^{\text {'93 }}$ But though Asquith was justified in refusing to proceed with controversial legislation in wartime, he had serious practical objections to the scheme. He was disturbed by the heavy cost involved and disliked the opportunities for corruption which would be opened up by such a vast extension of state ownership and patronage. Nor was he convinced by Lloyd George of the necessity for such drastic action. When the archbishop of Canterbury had discussed the matter with him in March, the prime minister had asked for further evidence. This the archbishop had gone to some lengths to collect by writing to clergymen in industrial centres, ports and garrison towns. Most were in favour of some additional restrictions but there were sufficient exceptions to raise doubts about wholesale measures. The bishop of Sheffield, for example, considered 'the attitude of the Sheffield Armament men is beyond all praise' and was opposed to further action. F. O. T. Hawkes, vicar of Aldershot suggested only bringing forward closing time by one hour, adding 'there is not a great deal of drunkenness now'. ${ }^{94}$

The proposals which Asquith and his cabinet eventually allowed Lloyd George to put before the commons fell far short of the original plan. On 24 April rgis the chancellor proposed an amendment to the defence of the realm act which would set up a central control board to regulate entirely the supply of alcohol in munition-making areas. By the end of 1916 the whole country apart from a few rural areas had passed under its supervision. In most places the board instituted the shortest drinking hours ever known, made treating illegal, diluted the strength of spirits, and began the great 'Carlisle experiment' in which the state purchase plan was put into operation in an area of fifty square miles. Despite the doubts of both friends and foes of the temperance cause, the total consumption of absolute alcohol in Great Britain

${ }^{99}$ George B. Wilson, Looking Back (London 1944) P I7; Lewis 23 October 1915; Lloyd George p 198.

${ }^{94}$ Lloyd George MS C/6/1I/38 R. T. Davidson-H. H. Asquith 30 March I9I5. 
dropped from eighty nine million gallons in I9I4 to thirty seven million in $1918 .{ }^{95}$

The first world war had three long years yet to run, and at various times calls were heard for further action to restrict the manufacture and sale of drink, particularly in I9I7 when there was a severe shortage of grain and sugar. By that time, however, Lloyd George had gone off the subject. He always insisted that it was in IgI 5 that the golden opportunity for a final solution had presented itself and been lost. According to Robertson Nicoll, he blamed the nonconformists, presumably because most of the members of the UKA were nonconformists. The UKA secretary blamed the churches in general for not coming out whole-heartedly for total prohibition. The bishop of Lincoln blamed Asquith. "What a touchstone the "Drink" question is!' observed bishop Hicks. For him it was the decisive factor in weighing the worth of national leaders. 'Asquith will not give up his liquor', he told C. P. Scott, 'this is the bottom of it', but Lloyd George 'is the biggest and best man of them all'. ${ }^{96}$ This conclusion was also beginning to dawn on some of the unionist leaders. Lloyd George's attack on his supporters in the commons over the Welsh church and his consultations with the opposition in March created such a favourable impression that Lord Beaverbrook believed that "the "Drink" problem smoothed the way towards Coalition'.97 It did not, however, smooth the way for Lloyd George in Wales. In October I9Is Herbert Lewis noted that when Lloyd George's name had been mentioned at the Liverpool meetings of the North Wales temperance association 'there was not the faintest breath of applause and the same was the case at a meeting . . . at Llanelly'. Lewis did not attribute his hero's fall from grace directly to the events of the spring, he knew that 'at temperance meetings people think about other things than temperance'. In Liverpool there had been Welsh liberals who hated Lord Northcliffe and drew their own conclusions from his newly developed friendship with Lloyd George 'Lloyd George's old supporters think a man is

${ }^{05}$ Henry Carter, The Control of the Drink Trade. A Contribution to National Efficiency 1915-17 (London 1918); Michael E. Rose, 'The Success of Social Reform? The Central Control Board (Liquor Traffic) I91 5-2I', War and Society, ed M. R. D. Foot (London 1973) pp 7I-84.

${ }^{08}$ W. R. Nicoll-J. D. Jones 22 October I9Is quoted in J. D. Jones, Three Score Years and Ten (London 1940) pp 232 seq; G. B. Wilson, Nationalisation of the Liquor Trade. Ought the Churches to Advocate it? (London 1915) p 6; BM Scott MS 50908/82 E. L. Hicks-C. P. Scott 7 May 19 r 5.

${ }^{97}$ Beaverbrook p 74. 


\section{Drink and disestablishment in the first world war}

known by the company he keeps, and they don't like the company'. ${ }^{88}$

In analysing this episode it is important not to be so overwhelmed by the larger than life personalities that we ignore the social realities of the situation. Lloyd George was only able to manipulate events by playing upon the very real fears, anxieties and frustrations of an influential section of the British people. The precariousness of existence, so often commented upon by Edwardian social pessimists now found concrete reinforcement in the failure of the British armies to defeat the Germans. ${ }^{99}$ The Bangor speech had forged the link between the threat from without and the threat from within. At a time when some explanation was required for national failure, the focus on drink provided a framework through which the wider crisis could be perceived and acted upon. The drink agitation should not be isolated as an amusing, quixotic interlude but seen as one of a series of moral panics which swept British society both before and during the first world war. As such it should be viewed both historically and laterally. In fact it had two histories. The first would locate it in a succession of moral reform crusades; the second would associate it with a much wider and more ferocious right wing reaction which in Edwardian times had been manifest in the anti-aliens campaign, the naval scare, Lord Roberts' call for conscription, and the quest for national efficiency. ${ }^{100}$ In the I9IS campaign the moral authoritarianism of the temperance movement merged with the political authoritarianism of the right-wing diehards for whom the so-called drink problem was only one element in a wider ideological crusade to mobilise British society against both the internal and external enemy. The desire to deprive women and workers of drink was part of an attempt to put the clock back, to clean up Britain, to make England worth fighting for, to make England worthy of victory.

${ }^{98}$ Lewis 23 October 19Is.

${ }^{90}$ For a thorough discussion of Edwardian social pessimism see Hynes passim. David Newsome, 'The Assault on Mammon: Charles Gore and John Neville Figgis', JEH 17, 2 (1966) pp 227-41. For an example see Neville S. Talbot, 'The Modern Situation', Foundations. A Statement of Christian Belief in Terms of Modern Thought, ed B. H. Streeter (London 1912) cap 1.

${ }^{100}$ On moral panics see Stanley Cohen, Folk Devils and Moral Panics (London 1972). Cohen's work has been brilliantly utilised by Stuart Hall, 'Racism and Reaction', Five Views of Multi-Racial Britain (London 1978). In this section of my paper the influence of Hall's talk will be obvious. For Edwardian social panics: Bernard Gainer, The Alien Invasion (London 1972); Stuart Mews, 'Religion and Conscription 1906-16' (paper delivered to the conference of the Commission Internationale d'histoire Ecclésiastique Comparée at the university of Uppsala, 1977). 
Finally, it should be mentioned that there was one man who after this incident could never forget and could never forgive Lloyd George. King George V, ostensibly left high and literally dry for the duration of the war, for the rest of his life nursed a grievance. On I April I922, the seventh anniversary of the announcement of the king's pledge, he moaned not for the first time about it to Hensley Henson, now bishop of Durham. But on this occasion he revealed to Henson that he had in fact continued to drink his normal amount 'under doctor's orders' but had had to do so privately and been unable to offer drink to his guests. ${ }^{101}$ So even the king can not be absolved from that 'humbug and hypocrisy' which Lloyd George himself admitted 'saturated' the drink question. As well he might, for on 30 April 1915 he had admitted to one of his colleagues that he believed the shortages of ships and shells were primarily due to government mismanagement. 'The idea that slackness and drink, which some people talk so much about, are the chief causes of delay, is mostly fudge'. ${ }^{102}$

\section{University of Lancaster}

${ }^{101}$ Henson I April 1922.

${ }^{102}$ Riddell's diary Io April igis p 74; Addison p 73. 